\title{
EARLY YEAR TEACHERS' UNDERSTANDING AND IMPLEMENTATION OF SCIENCE PROCESS SKILLS
}

\author{
Ayodele Ogegbo, \& Umesh Ramnarain \\ Department of Science and Technology Education, University of Johannesburg (South Africa)
}

\begin{abstract}
The quality of South African learners' performance in science and mathematics continues to remain poor as reflected in National and International assessments. However, it is believed that learners' poor performance in these subjects could be attributed to their weak and/or disproportional exposure to science instructions during early childhood development. The research objective of this study was to explore teachers' understanding and implementation of science process skills (SPS) in the early years. Accordingly, data were collected using qualitative research design of one on one interviews and lesson observations with eight Grade R teachers that were purposively and convieniently selected. The result showed that though participants believe it is important to start teaching science to children in the early years, most of them don't have adequate understanding of the science concepts in the Grade R syllabus. Though teachers engaged learners in activities that allowed them to observe, describe, measure, classify, predict and communicate ideas during the observed lessons, most of the teachers were unable to describe SPS. However, six of the teachers attributed their ability to demonstrate the process activities to years of experience and indicated that the teaching qualification they have did not accurately prepare them to teach science in the early years. In addition, teachers expressed low level of confidence and competency in planning and demonstrating science activities in early years.
\end{abstract}

Keywords: Early childhood education, early year teachers, early years science, science process skills.

\section{Introduction}

Science and Technology pervades nearly every aspect of everyday life and lays claim to addressing existing and future economic, environmental, education and associated global problems. The Next Generation Science Standards (NGSS) of the United States suggests that the key goals of science education are to enable learners to investigate, feed their curiosity, improve their understanding of scientific practices, promote their cognitive and analytical skills in understanding the natural world (National Research Council (NRC), 2012). To accomplish this aim, teachers must focus on teaching learners how to think within a scientific framework. In this regard, many countries have adopted common standards for the improvement of science education and learning outcome in order to compete in the global economy (DeBoer, 2011). Despite the renewed efforts to set high standards for learning outcomes in science education, South Africa continues to suffer from challenges associated with learners' low level of confidence in their ability to solve science problems. This is evident in international studies like TIMSS where South African learners performed poorly in science and mathematics as compared to other countries (Reddy, Visser, Winnaar, Arends, Juan, Prinsloo, \& Isdale, 2016). Furthermore, South Africa has a history of progressing learners from one grade to the other with a pass mark of $30 \%$ in science and mathematics (Van Staden, \& Motsamai, 2017), this in turn influences the quality of learners' performance at National assessments (Seo, 2018).

Research attributes learners' poor confidence in solving science problems to weak nurturing and development of scientific knowledge and skills during early childhood development (Letaba, 2017). Worth (2010) establishes the increasing awareness and belief that science is an important area for developing effective learning skills and attitudes in early years. In this regard, the National Science Teachers Association (NSTA) of the United States affirms that teaching and learning science in the early years lays the foundation for fostering the interest, enthusiasm and trust of learners in solving problems as they advance in their education and career lives (NSTA, 2014). Nonetheless, many South African learners are not exposed to science activities in the early years, because of the confining of science topics within Life Skills' subject in the foundation phase curriculum (Minnaar, \& Naude, 2016). Thus, many early year 
teachers tend to limit children chances to study science and many children tend to use their childlike interpretations of scientific phenomena, since they are not exposed to activities that allow them to objectively learn, see and understand their environment (Minnaar, \& Naude, 2016). Although the importance of science education in early years is been globally stressed by researchers and educators (Worth, 2010), its practice seems to be limited and problematic within the South African context. Hence, this study explored teachers' perspectives of science teaching and science process skills (SPS) in the early years. More specifically, the following research question guided this study:

1. What are teachers' understanding and implementation of science process skills in early years classroom?

2. What are the perceived factors that influences teachers understanding and implementation of SPS in early years classroom?

\section{Theoretical framework}

"Science is both a body of knowledge that represents current understanding of natural systems and the process whereby that body of knowledge has been established and is continually extended, refined, and revised. Both elements are essential: one cannot make progress in science without an understanding of both. Likewise, in learning science one must come to understand both the body of knowledge and the process by which this knowledge is established, extended, refined, and revised" (Duschl, Schweingruber, \& Shouse, 2007, p. 26). Thus, Irvanto, Rohaeti, Widjajanti \& Suyanta (2017:1) described SPS as "cognitive and psychomotor skills" that children use in exploring and "solving problem" in the world around them. SPS includes indicators such as observing, measuring, sorting/classifying, inferring and predicting, experimenting, and communicating information, controlling variables, and representing data (Worth, 2010; Irvanto et al., 2017). This implies that SPS is a vital outcome in science education across all levels of learning and it is required as a useful skill in enhancing learners critical thinking (Irvanto et al., 2017). Since these process skills are important in supporting children's basic abilities for learning science, mathematics, and language literacy in early childhood (Worth, 2010), teacher's awareness and understanding of science content in the curriculum, and science processes becomes very crucial to the development of SPS in young children. With regards to this study, teacher's understanding and implementation of science in early years is explored based on the development of teaching/play activities using SPS indicators. It is assumed that classroom implementation of these processes would stimulate teachers' autonomous recognition of relationship with the children.

\section{Method}

A qualitative research paradigm (Creswell, \& Creswell, 2017) was adopted, as the study aimed at investigating the understanding and implementation of science process skills (SPS) by teachers in the early years. Eight Grade R teachers from four different schools in an inner city of South Africa were involved in this study. The rationale for using a multiple case design was to inform the case by generating possible outcomes for predetermined reasons on how teacher's interpretation of SPS relate to the nature of science teaching and learning in early childhood classrooms. The mean age of participants was 39 years with the youngest being 23 and the oldest being 60. All eight participants were females with teaching experience ranging from two to twenty years as shown in Table 1. The sampled schools have inadequately resourced science corners. Two methods of data collection namely: one on one interviews and lesson observations was used. The different method of data collected employed in this study provided researchers the ability to evaluate and examine observed lessons and then modify the teacher interview procedure to provide more clarity and follow up on important responses and findings (Corbin \& Strauss, 2015). Data collected from participants were analysed using content analysis of direct, selective, and condensed codes (Erlingsson \& Brysiewicz, 2017). 
Table 1. Biographic Information of participants.

\begin{tabular}{|l|l|l|l|l|}
\hline \multirow{2}{*}{ School } & $\begin{array}{l}\text { Participants } \\
\text { (Teacher) }\end{array}$ & Age & Qualification & $\begin{array}{l}\text { Teaching experience } \\
\text { (Years) }\end{array}$ \\
\hline \multirow{3}{*}{ S1 } & T1 & 27 & National Diploma in Educare (N6) & 3 \\
\cline { 2 - 6 } & T2 & 23 & $\begin{array}{l}\text { Bachelor of Education (Early Childhood } \\
\text { Development). }\end{array}$ & 2 \\
\hline \multirow{3}{*}{ S2 } & $T 3$ & 43 & Diploma in Human Resource Management & 9 \\
\cline { 2 - 6 } & $T 4$ & 35 & National Diploma in Educare (N4) & 6 \\
\hline \multirow{3}{*}{ S3 } & $T 5$ & 32 & Diploma in Grade R teaching & 9 \\
\cline { 2 - 6 } & $T 6$ & 42 & National certificate & 6 \\
\hline \multirow{3}{*}{ S4 } & $T 7$ & 53 & National Diploma in Educare (N6) & 20 \\
\cline { 2 - 5 } & $T 8$ & 60 & Diploma in Primary education & $\begin{array}{l}7 \text { years in South Africa } \\
18 \text { years in Zambia }\end{array}$ \\
\hline
\end{tabular}

\section{Findings}

To explore teachers' perspectives of SPS in early years, it is believed that teacher's awareness on the importance of teaching science in early years could influence their understanding and implementation of SPS in Grade R classroom. The discussion reflects around two key ideas based on patterns arising from data analysis. These are the teachers' awareness of science concepts in the Grade $\mathrm{R}$ syllabus which included their understanding of SPS, and challenges influencing teachers' implementation of SPS.

\subsection{Teachers' awareness of science concepts in the grade $R$ syllabus}

It was evident from the interpretation of interview responses that all participants believe that teaching science in the early years plays a significant role in preparing children for future challenges in the academic endeavour. This was obvious from their answers to question that discussed explored teachers' awareness about the value of teaching science in early years and how they teach science in their classrooms. According to their responses, T5 believes that teaching science at a younger age "brings interest into the young child because they learn to experience science more and more". Here the participants focused on fostering learners interest in science at an early age. Furthermore, T5's perception to science teaching in early years was similar to those of T7 and T8, as they also indicated that exposing children to science in early years develops their interest in the subject and help to overcome the common perception of science as a difficult subject among South African learners. T2 mentioned that teaching science in early childhood exposes children to basic information required for understanding their environment. However, further explanation on how participants teach science in their classrooms revealed that five of the teachers do not have adequate understanding of science concepts that are included in the life skills subject taught in the Grade R curriculum. For example, T1 indicated that if children are taught science in early childhood, "they get the opportunity and foundation on how to explore things and when they grow it becomes part of them, but eeerm, I don't really teach science to these children. Though sometimes I just take them outside to show them some plants and let them feel or see it". Here, T1 seems not to be sure if teaching plants was part of science even though she engages children in activities related to growing plants.

4.1.1. Teachers understanding of science process skills. Since science process skills are regarded as important outcomes in science education. Thus, participants were required to explain their understanding of science process skills and identify the SPS indicators that they practice in class. SPS according to T6: "Hmmm...my understanding is like...may be children ability to take time to understand what I am teaching and sometimes they understand their way not the way I expect them to understand". This implies that T6 lacks adequate understanding of what SPS entail. However, during her explanation on SPS indicators practiced in her class she said "For instance when i use blocks, I do tell the children to sort out the blocks according to colours, and in so doing, the children get to first observe the different colours available and then they are able to build their ability to classify". T7 however, believed that SPS entails -

"teaching them how to weigh different things, observing like for instance when we are dealing with different plants, growing plants.... you see, I teach them how to observe plants (when they are dead, when they start to grow and sometimes we can plough a bin and see how it grows 
up...if we put in the shade it won't grow because it needs sunrays to make it grow)....The see and experience it for themselves".

This implies that T7 teaches measuring and observation as SPS indicators as explained in her response, which was also observed during her lesson presentation on colour mixing. T7's response relates to that of T5, where SPS is seen as allowing children to observe, communicate ideas, draw conclusions and sorting out things according to shapes or colours. This was indicated when T5 said "Most times I explain to kids what they are expected to do first before carrying out the task, as a teacher I carry out the activity in their presence, then ask them questions such as did you see what happened, then I allow the kids to explain to me what they have seen that just happened ....this will allows me to know if they really understand what I am teaching. I allow them to see what they want they want to do and before finishing the whole thing, I ask them about their thought... as in what they think is going to happen if I do one thing or the other. Nevertheless, during the interview, the other five teachers were not able to give a definite description/explanation of their understanding of SPS. However, analysis of observed lessons revealed that all teachers engaged learners in activities that allowed them to observe, describe, measure, classify, predict and communicate ideas during their lesson presentation. For instance, during T1 and T8's lesson on my body, learners were required to interact with one another using pictures of body parts displayed on the board to identify and desrcibe parts of their own body. From another point of view, during T3 and T6's lesson presentation on my environment, children were given a task to draw their school. In this regard, they were expected to use the teacher's example to identify objects in their own diagram, sort out the different shapes in the diagram using specific colours and describe their drawing using specific attributes.

\subsection{Factors influencing teachers understanding and implementation of SPS in early years}

Analysis of participants response during the interview and lesson observation revealed lack of confidence and competence in planning and demonstrating science activities as a factor influencing teachers understanding and implementation of SPS in early years. Some of the teachers attributed their lack of confidence and poor competency to lack of learning resources. For example, T3 said "teaching science and this SPS is not difficult but the problem is we don't have any resources to teach the children. So, it becomes difficult for a teacher like me to plan a science activity effectively". This statement was also established by T7 when she said, "you see, teaching science to young children is not about talking, and though schools might not have enough resources for science teaching, teachers need to be creative around the lesson they want to teach". She believes that most teachers don't know how to implement science concepts for young children and teachers' ability to improvise resources serves as a way of building confidence and competency in science teaching.

The second challenge affecting teachers confidence and competency as revealed in this study is poor background knowledge in terms of science content and pedagogical knowledge. For instance, T8 indicated during the interview that teaching science is very challenging because "I did not get enough exposure in terms of the various methods to use to help young children understand a lesson better, and I don't even attend professional development program/workshop. So it is affecting me as a teacher because i just teach my lesson based on the available topics covered in the textbooks we use". T1's response was similar to T7's view on teachers not knowing how to teach science in early years. It is possible that early year teachers who find it difficult to teach science are not aware of the various teaching strategies that can be used to scaffold science activities for young children. T8 indicated that she also struggles with planning certain activities because she was not exposed to science content during her education program. She further explained that the kind of academic training she received was not okay to teach science subjects in the early years. In view of T8's response on academic qualification, six of the teachers however indicated that their experience over the years had greatly contributed to the science activities and process indicators that were implemented in the observed lessons. For instance, T5 said "You see, I believe my academic came in later. It is my experience that made me interested in getting the certificate which I believed I did just to back me up. In the real sense of it, my experience contributed a great deal to the knowledge and approach I now use in teaching science related activities to young children".

\section{Discussion and conclusion}

The data findings, in general, revealed that participants are receptive to teaching science in early years but did not feel qualified/confidence to teach science due to their academic qualification, and lack of resources. Though majority of the participants are qualified early year teachers according to South Africa's qualification framework, it was observed that their qualification did not adequately prepare them to meet the needs of science teaching in early years classrooms. It is believed that early year teachers do 
consider themselves confidence and competent in teaching science when science corner within the school/classroom is equipped with rich teaching materials, visual materials and hands on activities that can be used to teach science concepts (Dogan \& Simsar, 2018). Findings also revealed that years of teaching experience was found to be associated with participants awareness of science teaching, and implementation of SPS indicators as observed in their classroom practice, but not on their understanding of SPS. Science process skills of observing, and communication was commonly found in all the observed lessons, only two of the teachers implemented measure, classify, predict and communicate.

To encourage the development and implementation of science literacy in early years, findings from this study suggest emphasis be put on developing early childhood teachers conceptual and operational understanding of SPS during teacher education programs. Also, education stakeholders, childcare workers, policy makers and ECD practitioners should be actively involved in the formation and maintenance of support structures that enhance early year teachers' science knowledge and practice. This will help improve the quality of early year teachers in enhancing learners' participation and growth in science education within larger South Africa context. Furthermore, engaging children in inquiry projects and more hands-on play activities that are scientific oriented at a very early age may also lead to improving the quality of early childhood education in the country.

\section{References}

Concepts, and Core Ideas. Washington, DC: The National Academies Press. https://doi.org/10.17226/13165.

Corbin, J. \& Strauss, A. (2015). Basics of qualitative research: Techniques and procedures for developing grounded theory (4th ed.). Los Angeles, CA: Sage Publications.

Creswell, J. W., \& Creswell, J. D. (2017). Research design: Qualitative, quantitative, and mixed methods approaches. Sage publications.

DeBoer, G., E. (2011). The globalization of science education. Journal of Research in Science Teaching, 48(6), 567-591. Retrieved from https://onlinelibrary.wiley.com/doi/abs/10.1002/tea.20421

Dogan, Y., \& Simsar, A. (2018). Preschool teachers' views on science education, the methods, they use, science activities and the problems they face. International Journal of Progressive Education, $14(5), 57-76$

Duschl, A. R., Schweingruber, A. H., \& Shouse, W.A (2007). Taking science to school: Learning and teaching science in grades k-8. Washington DC: The National Academic Press.

Erlingsson, C., \& Brysiewicz, P. (2017). A hands-on guide to doing content analysis. Africa Journal of Emergency Medicine, 7 (3), 93 - 99.

Irvanto, Rohaeti, E., Widjajanti, E., \& Suyanta (2017, August). Students' science process skill and analytical thinking ability in chemistry learning. American Institute of Physics Conference Proceedings 1868, 030001. Retrieved from https://doi.org/10.1063/1.4995100

Letaba, P. (2017). South African performance on the trends in international mathematics and science study. The National Advisory Council on Innovation.

Minnaar, R. \& Naude, F. (2016, October). Grade R teachers' awareness of the development of science process skills in children. Paper presented at the ISTE International Conference on Mathematics, Science, and Technology Education, Limpopo, South Africa. Retrieved from http://uir.unisa.ac.za/handle/10500/22896

National Research Council (2012). A Framework for K-12 Science Education: Practices, Crosscutting

National Science Teachers Association. (2014). NSTA position statement: Early childhood science education. Science and Children, 51(7), 10-12.

Reddy, V., Visser, M., Winnaar, L., and Arends, F., Juan, A Prinsloo, C.H. \& Isdale, K. (2016). TIMSS 2015: Highlights of Mathematics and Science achievement of Grade 9 South African Learners. Human Sciences Research Council

Seo, B., I (2018, September). Understanding grade 8 and grade 9 math teachers' manipulation of mathematical language during lessons of story problem comprehension. Paper presented at the South Africa International Conference on Education, Pretoria, South Africa.

Van Staden, S., \& Motsamai, P. (2017). Differences in the quality of school-based assessment: Evidence in Grade 9 mathematics achievement. Pythagoras, 38(1), 1-10.

Worth, K. (2010). Science in early childhood classrooms: Content and process. Early Childhood Research \& Practice (ECRP), 12(2). 